\section{Lasten huoltorasituksen jakaantuminen}

\author{
Valtiot. maist. ANTERO PERÄLÄINEN \\ Väestöliitto
}

Lasten huoltorasituksen jakaantumista on tarkasteltu Pekka Kuusen kirjassa $>60$ luvun sosiaalipolitiikka». Siinä yhteydessä esitettiin tämän kirjoittajan laatima taulukko, jossa väestö oli jaettu lapsia huoltaviin ja huoltovelvollisuutta vailla oleviin aikuisiin. Taulukko osoitti, että $28 \%$ väestöstä kuului siihen ryhmään, jonka huollettavana oli vähintään kaksi lasta. Tämän ryhmän huollettavana oli $81 \%$ kaikista alle 16-vuotiaista lapsista. Loppuosa lapsista eli 19 \% kuului perheisiin, joissa oli vain yksi lapsi. Tämä laskelma tehtiin lapsilisätilaston pohjalta. Yhden huoltajan varassa olevien lasten osalta jouduttiin turvautumaan tämän kirjoittajan elatusapukomiteaa varten laatimiin melko karkeisiin arvioihin. Kun äskettäin on ilmestynyt vuoden 1960 väestölaskennan täydennysosassa tarkempi erittely yhden huoltajan lapsiperheistä ja heidän siviilisäädystään, on tarjoutunut tilaisuus tarkistaa tätä huoltorasitusta koskevaa laskelmaa.

Väestölaskenta suoritetaan ruokakunnittain, mutta lapsia ei ole tilastoitu siinä vaan perhetilaston yhteydessä. Näin ollen kasvattilapset - samoin kuin laitoksissa olevat lapset - eivät esiinny perhetilastossa. Nämä kaksi ryhmää on oheisessa taulukossa 1 merkitty erikseen. Lapsilisätilastosta voidaan päätellä, että suurin osa näistä lapsista on kasvattilapsia tai muita perhehoidossa olevia lapsia.

Lapsen ylin ikäraja on väestölaskennassa 18 vuotta. Sen vuoksi oheisessa taulukossakin on menetelty näin, koska tämä antaa paremman kuvan tosiasiallisesta elatusrasituksesta kuin lapsilisätilaston 16 vuo- den ikäraja. Suurin osa 16-17-vuotiaista lapsista nimittäin jatkaa opintojaan nykyisin joko lukiossa tai erilaisissa ammattikouluissa. Jos kaikki opintojaan jatkavat lapset otettaisiin lukuun, huollettavien lasten lukumäärä saattaisi kohota vielä hieman suuremmaksikin kuin tässä laskelmassa olevien lasten määrä.

Yksinäisiksi huoltajiksi on katsottu nainen ja lapsia-ryhmään kuuluvista lapsiperheistä ne, joissa nainen oli leski, eronnut tai avioliiton ulkopuolella synnyttänyt; avioliitossa olevat tähän ryhmään kuuluvat luettiin muiden perheiden joukkoon. Mies ja lapsia-ryhmään kuuluneet perheet katsottiin kaikki yksinäisiksi huoltajiksi, koska tätä pienehköä ryhmää ei ole eritelty siviilisäädyn mukaan.

Taulukosta 1 käy ilmi, että pääosa lastenhuoltorasituksesta lankeaa niille lapsiperheille, joissa on huollettavana yksi tai useampia lapsia yhtä aikuista kohden: 30 prosenttia aikuisesta väestöstä huoltaa valtaosan eli 84 prosenttia kaikista lapsista. Muut lapset kuuluvat sellaisiin perheisiin, joissa kaksi aikuista yksin huoltaa yhtä lasta. Koko väestöstä kuuluu noin 45 prosenttia näihin lastenhuoltajien ryhmiin.

Runsas toinen puoli väestöstä ei siis tämän laskelman mukaan osallistu varsinaisesti lasten huoltoon. Heidän joukossaan on kuitenkin joitakin, jotka saattavat avustaa lastenhuoltajia. Tällaisia ovat $\mathrm{mm}$. sellaiset avioeron saaneet miehet ja avioliiton ulkopuolella syntyneiden lasten elatusvelvolliset, jotka eivät olleet toisen lapsiperheen päämiehiä väestölaskennan aikana. Kasvattilapsia on voinut myöskin 
Taulukko 1. Lastenhuoltorasitus 31. 12. 60 väestölaskennan mukaan.

\begin{tabular}{|c|c|c|c|c|}
\hline \multirow[b]{3}{*}{ Aviopuolisot } & \multicolumn{2}{|c|}{$\begin{array}{c}\text { A ikuiset } \\
18-v\end{array}$} & \multicolumn{2}{|c|}{$\begin{array}{l}\text { Lapset } \\
0-17 \mathrm{v} .\end{array}$} \\
\hline & luku & $\%$ & luku & $\%$ \\
\hline & & & & \\
\hline joilla lapsia 5 tai useampia & 103674 & 3.6 & 305421 & 19.4 \\
\hline$\Rightarrow \quad>\quad 4$ & 107208 & 3.7 & 214416 & 13.6 \\
\hline$\Rightarrow \quad 3$ & 212834 & 7.4 & 319251 & 20.3 \\
\hline$>\quad>2$ & 375026 & 13.1 & 375026 & 23.9 \\
\hline Yksinäiset huoltajat joilla lapsia & 65812 & 2.3 & 109487 & 7.0 \\
\hline Yht. & 864554 & 30.1 & 1323601 & 84.2 \\
\hline Aviopuolisot joilla 1 lapsi & 425726 & 14.8 & 212863 & 13.5 \\
\hline Yht. & 1290280 & 44.9 & 1536464 & 97.7 \\
\hline Lapsettomat avioparit & 716448 & 24.9 & & \\
\hline Yksinäiset henkilöt joilla ei lapsia & 866751 & 30.2 & & \\
\hline Kasvatti- ja lastenkotien lapset & & & 36279 & 2.3 \\
\hline Yht. & 2873479 & 100.0 & 1572743 & 100.0 \\
\hline
\end{tabular}

olla tässä taulukossa lapsettomaksi merkityn perheen tai yksinäisen henkilön elätettävänä.

Suurin osa lapsettomista aviopareista on ilmeisesti sellaisia, jotka aikaisemmin ovat huoltaneet lapsia; pieni osa on nuoria aviopareja, joille ei vielä ollut syntynyt lasta. Yksinäisten henkilöidenkin joukossa on paljon leskiä ja eronneita, joilla on ollut omia lapsia. Erityistä selvitystä ei ole saatavissa siitä, kuinka suuri osa väestös- tä jossain elämänsä vaiheessa on osallistunut lasten elatukseen. Aviopareista on vajaan kymmenennen osan arveltu jäävän pysyvästi lapsettomiksi, mutta osa näistäkin on voinut ottaa ottolapsen tai kasvatin tahi avioeron tapahduttua huoltanut lasta toisessa avioliitossa.

Vuoden 1960 jälkeen tapahtuneesta kehityksestä voidaan lapsilisätilaston ja väestöennusteen nojalla päätellä, että 60 -luvun loppuun mennessä lasten kokonaisluku-

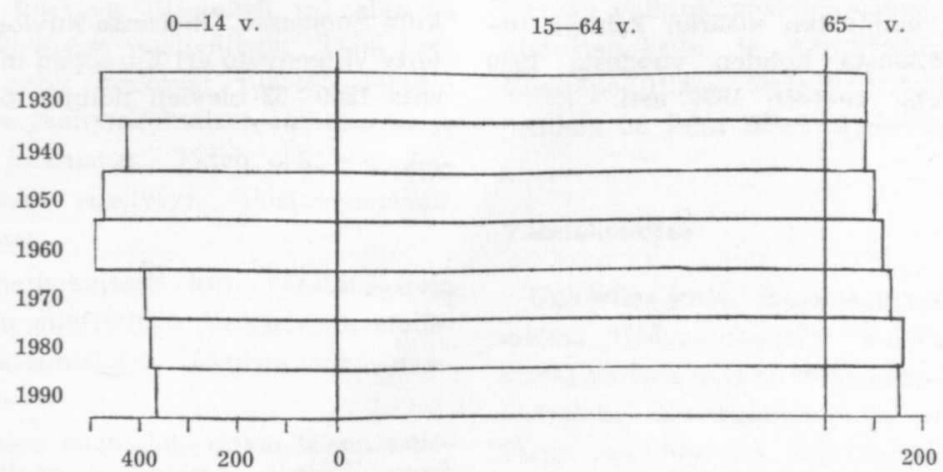

Kuvio 1. Lapsia ja vanhuksia tuhatta 15-64-vuotiasta kohden Suomessa. 


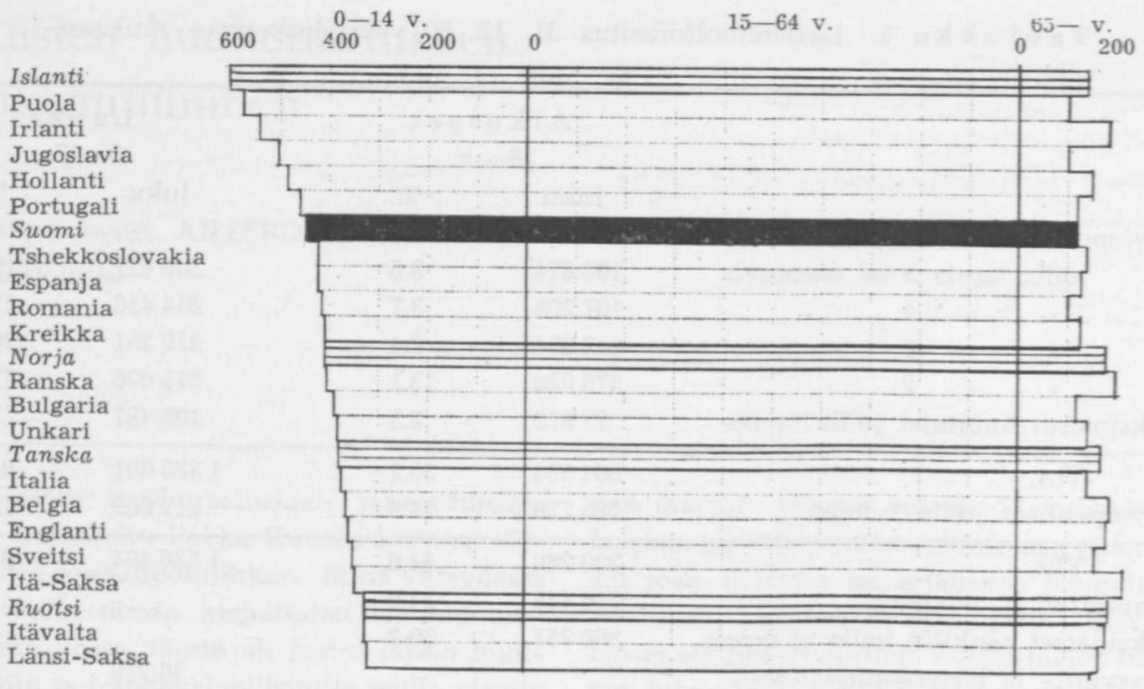

K uvi o 2. Lasten $(0-14$ v.) ja vanhusten (65-v.) määrä tuhatta työikäistä $(15-64$ v.) kohti.

määrä tulee alenemaan noin 8 prosenttia. Tähän on syynä se, että suuret ikäluokat tulevat poistumaan lasten joukosta parin vuoden kuluttua,

Lastenhuoltorasitusta tutkittaessa menetellään usein siten, että lasketaan kuinka palịon lapsia on tuhatta työikäistä kohden. Tällöin työikäisillä tarkoitetaan 1564-vuotiaita, lapsilla $0-14$-vuotiaita ja vanhuksilla 65 vuotta täyttäneitä. Tilastollisen päätoimiston laatima väestöennuste osoittaa tämän laskutavan mukaan, että lastenhuoltorasitus tulee lähivuosina alenemaan, mutta vanhusten hieman kasvamaan. Oheisessa kuviossa 1 on esitetty lasten ja vanhusten määrän kehitys tuhatta työikäistä kohden vuodesta 1930 alkaen sekä vuoteen 1990 asti.
Tuhatta 15-64-vuotiasta kohden on

$\begin{array}{ccc}\text { vuonna } & \begin{array}{c}\text { lapsia } \\ 0-14 \mathrm{v} .\end{array} & \begin{array}{c}\text { vanhuksia } \\ 65-\mathrm{v} .\end{array} \\ 1950 & 473 & 104 \\ 1960 & 482 & 118 \\ 1970 & 391 & 135 \\ 1980 & 378 & 158 \\ 1990 & 368 & 155\end{array}$

Jos tämän saman laskutavan mukaan verrataan tilannetta Euroopan eri valtioissa, havaitaan Suomen olevan lapsirikkaimpien maiden joukossa (kuvio 2). Islantia lukuunottamatta kaikissa muissa pohjoismaissa on lapsia suhteellisesti vähemmän kuin Suomessa. Oheisessa kuviossa on esitetty yhteenveto eri Euroopan maista vuosilta $1960-62$ olevien tietojen perusteella. 